\title{
DEVELOPING A NEW FORMULA FOR ESTIMATING BIRTH WEIGHT AT TERM PREGNANCY
}

\author{
Risanto Siswosudarmo ${ }^{1}$, Intan Titisari ${ }^{2}$
}

\begin{abstract}
ABSTRAK
Latar belakang: Taksiran berat janin (TBJ) dipakai untuk panduan melakukan manajemen persalinan. Beberapa cara telah dipakai untuk mengukur taksiran berat lahir bayi misalnya dengan palpasi abdomen, pengukuran tinggi fundus uterus ibu (TFU) dan pemeriksaan ultrasonografi. Pengukuran tinggi fundus uterus ibu nampaknya merupakan cara yang paling sederhana dan murah dan dapat dikerjakan oleh semua tenaga kesehatan.

Tujuan penelitian: Membuat rumus baru berdasarkan pengukuran tinggi fundus uterus ibu.

Rancangan dan cara penelitian: Rancangan penelitian ini adalah studi cross sectional dengan mengukur TFU pada kehamilan 37-42 minggu di kamar bersalin RS Sardjito dan RS Jejaring. Sebanyak 655 ibu hamil yang memenuhi kriteria kelayakan dimasukkan dalam penelitian ini. Tinggi fundus diukur dengan pita non elastik flksibel dari simfisis pubis sampai puncak tinggi uterus pada saat pasien dalam persalinan kala satu. Berat lahir bayi (BLB) ditimbang dengan timbangan bayi yang sama setelah semua dikalibrasi. Analisis regresi linear digunakan untuk menghitung korelasi dan menentukan rumus TBJ berdasar TFU.

Hasil: Sejumlah 655 ibu hamil yang memenuhi kriteria kelayakan dengan umur kehamilan antara 37 sampai 42 minggu masuk dalam penelitian ini. Sebagian besar mereka berumur antara 20 to 30 tahun, sedang paritasnya berimbang. Rata-rata TFU adalah 31,25 $\pm 2,35 \mathrm{~cm}$ (bervariasi dari 24 sampai $38 \mathrm{~cm}$ ) dan rata-rata BBL adalah 3021,60 \pm 341,14 gram (bervariasi dari 2050 to 4250 gram). Koefisien korelasi Pearson adalah 0.93 ( $R$ square 0.86), yang menunjukkan adanya korelasi yang kuat antara TFU dengan BBL. Rumus TBJ berdasar TFU adalah adalah Y (BBL dalam gram) $=125 X$ (TFU dalam $\mathrm{cm})-880$.

Kesimpulan: Terdapat hubungan yang kuat anatara TFU dengan BBL, di mana rumus untuk mengestimasi $B B L$ adalah $\mathrm{BBL}=125 \mathrm{TFU}-880$.
\end{abstract}

Kata kunci: Estimasi berat lahir, Tinggi fundus uterus, Berat bay lahir, Rumus Risanto

\begin{abstract}
Background: Estimated birth weight (EFW) is used as a guidence for management of labor. Several methods are used from abdominal palpation, measurement of fundal height and ultrasound examination. For the shake of simplicity fundal height measurement to be the simplest and cheapest way that can be done by all medical personnels.

Objective of study: To develop a new formula in determining estimated birth weight based on maternal symphisis fundal height $(\mathrm{FH})$.

Material and method: A cross sectional study was used, consisting of 655 pregnant women from Sardjito and affiliated hospitals at 37-42 weeks of gestation. Fundal height was measured from the symphisis to the top of uterine fundus, using inverted unelastic flexible tape. Infant birth weight (IBW) was determined by the same baby scale after calibrated. Linear regression analysis was used to calculate the correlation and develop the formula.

Result: A total of 655 pregnant mothers meeting the inclusion criteria from 37 to 42 weeks of gestation were recruited. Most of them were between 20 to 30 years old and their parity were almost comparable. The mean $\mathrm{FH}$ was $31.25 \pm 2.35 \mathrm{~cm}$ (ranged between 24 to $38 \mathrm{~cm}$ ) and the mean IBW was $3021.60 \pm 341.14$ grams (ranged between 2050 to 4250 grams). The Pearson correlation was 0.93 (R square 0.86), signifying that there was a
\end{abstract}

\footnotetext{
1,2 Bagian Obstetri dan Ginekologi, Fakultas Kedokteran UGM
} 
strong correlation between FH and IBW. The formula for estimating IBW based on FH was Y (IBW in gram) $=125$ $X(\mathrm{FH}$ in $\mathrm{cm})-880$.

Conclusion: There was a strong correlation between FH and IBW. The formula for estimating IBW was IBW $=125$ $\mathrm{FH}-880$.

Key words: Estimating birth weight, Fundal height, Fetal birth weight, Risanto's formula.

\section{INTRODUCTION}

Size of the fetus is one factor influencing prognosis of the second stage of labor. Estimating accurate birth weight before labor is important as mode of delivery may be different. Large or small birth weight infants might give rise to a serious problem to the neonates and their following development. Appropriate mode of delivery based on baby's size and birth weight could be reducing the poor effect of the pregnancy outcome especially for the baby. ${ }^{1}$

Fundal height has been proven to be correlated with pregnancy age and infant weight. Based on the Johnson's formula, Johnson EFW (JEFW) is calculated as follows: JEFW $=(F H-n) \times 155$, where EFW is in gram, $\mathrm{FH}$ in $\mathrm{cm}, \mathrm{n}=12$ if the fetal head is unengaged, and $n=11$ if the fetal head is engaged. ${ }^{2}$ The fundal height, however, is influenced by some factors such as maternal size, parity, fetal sex and ethnic. The Johnson formulas has been used so widely although it is based on western women.

In 1995 the new formula was developed by Siswosudarmo to estimate the infant birth weight based on maternal fundal height. Based on 560 maternal fundal height meausurement of pregnant women in the Province of Jogjakarta, Siswosudarmo found the formula to estimate infant birth weight. The formula is then called the Risanto's formula for estimating fetal weight (REFW), the equation of which was as follows: $Y=126.7 X-931.5$ where $Y$ was EFW in grams, $X$ was maternal fundal height in $\mathrm{cm}$ and 931.5 was the constanta. ${ }^{3}$ This formula has been tested by Titisari and Siswosudarmo ${ }^{4}$ by comparing with Johnson formula and the result showed that it was more accurate.
As the previous Risanto's formula was based on the secondary data taken from medical record, the Author woud like to reformulate it. The aim of the present study, therefor, is to reformulate the new calculation of Risanto's formula based on measurement of maternal symphisis-fundal height on 655 pregnant mothers at their onset of labor.

\section{MATERIAL AND METHOD}

This was a cross sectional study conducted at Sardjito and 16 affiliated hospital in Central Jawa which might represent Malay race. All pregnant women meeting the inclusion criteria such as at 37 to 42 week gestational age, singleton baby, cephalic presentation, alive fetus and during the latent phase of labor were included. Mothers with uncertain age gestational age, polihydramnios, and fetal anomalies were excluded.

Fundal height measurement was carried out by the Resident in charge with the following ways: Mother was in supine position with both hips and knees joints flexed. In case of full bladder, she was asked to void. Fundal height was measured during no contraction using flexible non-elastic tape (sewing tape) from the symphisis pubis to the top of the uterine fundus. If the uterus was slanting, an assistant was asked to fix the uterus in the midline. Measurement was done twice with the inversed tape to avoid bias, during the first stage of labor. If during the first 24 hours patients didn't give birth, then the new measurement was done. The baby was weighed during the first hours after delivery using the same baby scale after calibrated. Data were recorded using the provided forms. 


\section{RESULTS AND DISCUSSION}

A total of 655 pregnant mothers meeting the inclusion criteria were recruited, and their characteristics were shown in Table 1.

Table 1. Characteristics of study subjects

\begin{tabular}{lcc}
\hline \multicolumn{1}{c}{ Characteristics } & $\mathrm{N}$ & Percent \\
\hline Age (year) & & \\
$\quad<20$ & 56 & 8.6 \\
$20-30$ & 388 & 59.2 \\
$\quad>30$ & 211 & 32.2 \\
Parity & & \\
$\quad$ Primiparous & 326 & 49.8 \\
$\quad$ Multiparous & 329 & 51.2 \\
Gestational age (weeks) & & \\
$\quad$ 37-41 & 513 & 73.3 \\
$\quad>41$ & 412 & 21.7 \\
Body mass index (BMI) & & \\
$\quad$ Normal & 283 & 43.2 \\
$\quad$ High & 372 & 56.8 \\
\hline
\end{tabular}

The maternal fundal height (FH) and infant birth weight (IBW) were shown on the following table.

Table 2. Maternal fundal heght (FH) and the actual infant birth weight (IBW)

\begin{tabular}{lrrrrr}
\hline & N & Minimum & Maximum & \multicolumn{1}{c}{ Mean } & \multicolumn{1}{c}{ SD } \\
\hline FH in cm & 655 & 24 & 38 & 31.25 & 2.53 \\
IBW in grams & 655 & 2050 & 4250 & 3021.60 & 341.14 \\
\hline
\end{tabular}

The corelation between $\mathrm{FH}$ and IBW was calculated using linear regression analysis and the result was seen in the following figure (FIGURE1),

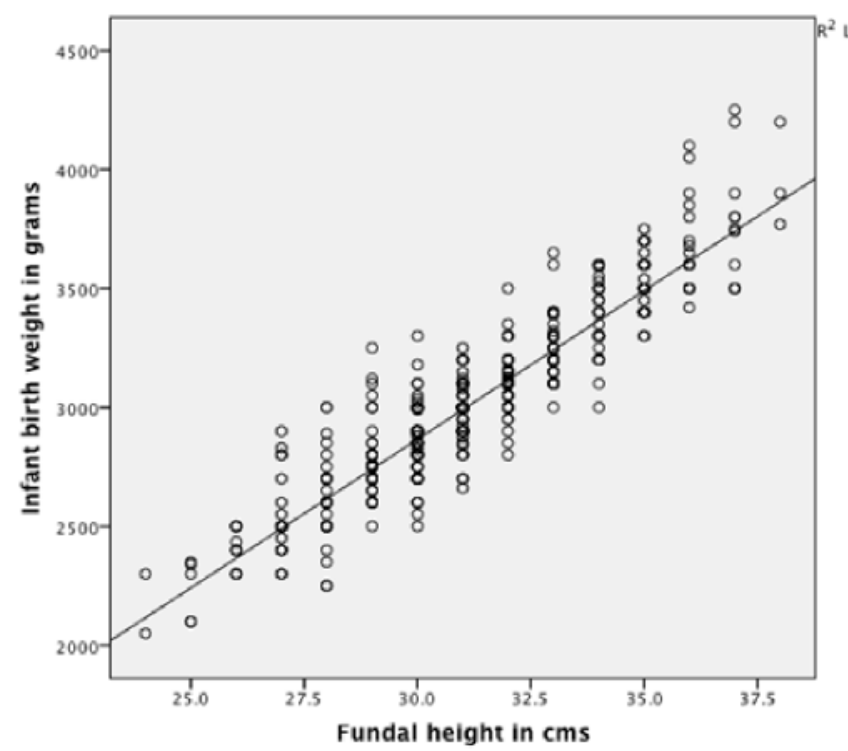

Figure 1.Correlation of fundal height and infant birth weight. 
Table 3. The equation of estimated birth weight (gram) based on maternal fundal height $(\mathrm{cm})$

\begin{tabular}{lcccc}
\hline Variables & B & $95 \% \mathrm{Cl}$ for B & P values & R square \\
\hline Constanta & -881.31 & $-1003.40--759.13$ & .00 & 0.86 \\
Fundal height & 124.90 & & & \\
\hline
\end{tabular}

The equation was:

$Y=124.90 X-881.31$, where

$Y=$ Infant birth weight in grams

$X=$ Fundal height in $\mathrm{cm}$

This equation could be simplified as follows:

$$
Y=125 X-880
$$

Using this formula, the estimated IBW for a given fundal height was put on the following table (Table 4).

Table 4. Estimated Birth Weight Based on The New Risanto's Formula

$$
\mathrm{EBW}(\mathrm{gram})=125 \times \mathrm{FH}(\mathrm{cm})-880
$$

\begin{tabular}{|c|c|}
\hline $\mathrm{FH}(\mathrm{cm})$ & EBW (gram) \\
\hline 25.0 & 2245.0 \\
\hline 25.5 & 2307.5 \\
\hline 26.0 & 2370.0 \\
\hline 26.5 & 2432.5 \\
\hline 27.0 & 2495.0 \\
\hline 27.5 & 2557.5 \\
\hline 28.0 & 2620.0 \\
\hline 28.5 & 2682.5 \\
\hline 29.0 & 2745.0 \\
\hline 29.5 & 2807.5 \\
\hline 30.0 & 2870.0 \\
\hline 30.5 & 2907.5 \\
\hline 31.0 & 2995.0 \\
\hline 31.5 & $3.057,5$ \\
\hline 32.0 & 3120.0 \\
\hline 32.5 & 3182.5 \\
\hline
\end{tabular}

\begin{tabular}{|c|c|}
\hline $\mathrm{FH}(\mathrm{cm})$ & EBW (gram) \\
\hline 33.0 & 3245.0 \\
\hline 33.5 & 3307.5 \\
\hline 34.0 & 3370.0 \\
\hline 34.5 & 3432.5 \\
\hline 35.0 & 3495.0 \\
\hline 35.5 & 3557.5 \\
\hline 36.0 & 3620.0 \\
\hline 36.5 & 3682.5 \\
\hline 37.0 & 3745.0 \\
\hline 37.5 & 3807.5 \\
\hline 38.0 & 3870.0 \\
\hline 38.5 & 3932.5 \\
\hline 39.0 & 3995.0 \\
\hline 39.5 & 4057.5 \\
\hline 40.0 & 4120.0 \\
\hline 40.5 & 4182.5 \\
\hline
\end{tabular}


Many methods were used to estimate fetal weight, because no direct measurement was available. The convensional methods was palpation of the maternal abdomen. It varied widely because of it was infulenced by maternal characteristics such as thickness of the abdominl wall, obesity and maternal height. ${ }^{5}$ Fundal height, therefore had the better sensitivity than maternal palpation, maternal height and weight, and midle upper arm circumference. ${ }^{6}$

The more recent method widely used to estimate fetal weight was using ultrasound examination. A study involving 190 subjects to compare the accuracy of abdominal palpation, Johnson's formula and ultrasound examination to estimate infant birth weight was done. The result showed that there were a significant correlation between birth weight and the variables mentioned above. ${ }^{7}$ Another study done in Thailand showed that EFW using Johnson formula gave an excessive weight 227.17 grams $(95 \% \mathrm{Cl}$ 205.91-244.83). ${ }^{8}$

An equation to predict birth weight based on symphysis fundal height (SFH) was done by Buchmann dan Tlale. ${ }^{9}$ In their study, the derivation study $\mathrm{N}=504$ ), birth weight was predicted by the equation: birth weight in $\mathrm{g}=301+78$ (SFH in $\mathrm{cm}$ ). This was transformed to the simplified formula: birth weight in $\mathrm{g}=100$ ([SFH in $\mathrm{cm}]-5)$. Using this formula for the data set, $68.1 \%$ of birth weight estimates were correct to within $10 \%$ of the birth weight. For prediction of birth weight $\geq 4000 \mathrm{~g}$, an SFH measurement of $40 \mathrm{~cm}$ had a sensitivity of $82 \%$ and a specificity of $80 \%$. In the validation study ( $N=294)$, the derived simplified formula gave $65.0 \%$ of estimates correct to within $10 \%$ of the birth weight. The predictive values of the $40 \mathrm{~cm}$ SFH cut-off were similar to those in the derivation study.

\section{CONCLUSION}

This study which was done in the Province of Jogjakarta and Central Jawa (represent Malay race) was using a better methodology than the author had done in 1995. The new Risanto formula, EBW (gram) $=\mathbf{1 2 5} \mathrm{X} \mathrm{FH}(\mathrm{cm})-\mathbf{8 8 0}$, was expected to be more precise than previous one.

\section{REFERRENCES}

1. Etikan I, Caglar M. Prediction methods for babies birth weight using linear and nonlinear regression analysis. Technology and Health Care, 2005; 13: 131-135.

2. Pernoll ML. Handbook of Obstetrics and Gynecology. $10^{\text {th }}$ ed, Singapore: The Mc Graw Hill Medical Publishing Division, 2001:117

3. Siswosudarmo HR. Deteksi Bayi Berat Lahir Rendah pada Kehamilan Aterm dengan Pengukuran Tinggi Fundus. Berkala Epidemiologi Klinik \& Biostatika Indonesia, 1995; 1 (20):78-84.

4. Titisari HI, Siswosudarmo HR. Risanto's Formula is more Accurate in Determining Estimated Fetal Feight Based on Maternal Fundal Height. Maj Obstet Ginekol 2013; 1-3:149-51.

5. Mongelli M, Gardosi J. Symphysis-fundus height and pregnancy characteristics in ultrasound-dated pregnancies. J Obstet Gynecol, 1999: 94: 591-594

6. Walraven G, Mkanje R, Van Roosmalen J, Van Dongen P, Van Asten H, Dolmans W. 'Single predelivery symphysis-fundal height measure-ment as a predictor of birthweight and multiple pregnancy'. British J Obstet Gynecol, 1995; 102: 525-529.

7. Khani S, Ahmad-Shirvani M, Mohseni-Bandpei MA, Mohammadpour-Tahmtan RA. Compa-rison of abdominal palpation, Johnson's technique and ultrasound in the estimation of fetal weight in Northern Iran. Midwifery 2011; 27(1):99-103.

8. Numprasert W. A Study In Johnson's Formula: Fundal Height Measurement for Estimation of Birth Weight, Assumption University Journal, 2004; 8 (1): 15-20.

9. Buchmann, E. Tlale, K. A simple clinical formula for predicting fetal weight in labour at term - derivation and validation. South Africa Medical Journal, 2009;99: 457-460 